\title{
A New Species of Genus Clathria (Microciona) (Demospongiae: Poecilosclerida: Microcionidae) from Jejudo Island, Korea
}

\author{
Hye Ri Kim and Chung Ja Sim* \\ Department of Biological Sciences, College of Life Sciences and Nano Technology, \\ Hannam University, Daejeon 305-811, Korea
}

\begin{abstract}
A new species of genus Clathria (Microciona) (Demospongiae: Poecilosclerida: Microcionidae), Clathria (Microciona) sinyangensis n. sp. was collected from Intertidal zone by hand at Seopjikoji, Sinyang, Jejudo Island, Korea on 15 Oct. 2008. C. (M.) sinyangensis n. sp. is closely related to C. (M.) pennata Lambe, 1895 in their spicules, but thick subtylostyle of new species is smaller than that of $C$. (M.) pennata's and has three sizes of toxa. Also, the new species has no dermal membrane.
\end{abstract}

Key words: Clathria (Microciona), Microcionidae, Korea

\section{INTRODUCTION}

The Clathria (Microciona) is characterized by encrusting growth form, with hymedesmioid skeletal architecture consisting of a basal layer of spongin, typically with ascending, plumose, and style in megascleres embedded and erect on basal layer. 103 species of subgenus Microciona reported from world wide (Hooper, 1996; Hooper and van Soest, 2002). Four species of Clathria (Microciona) have been reported from Korean waters (Rho and Lee, 1976; Sim and Byeon, 1989; Sim et al., 1992).

The material examined in this study was collected from Intertidal zone by hand at Seopjikoji, Sinyang, Jejudo Island, Korea on 15 Oct. 2008. All procedures were followed the methods of Kim and Sim (2005) and Rützler (1978). The specimens examind were deposited in the Natural History Museum and Department of Biological Sciences, Hannam University, Daejeon, Korea.

\section{SYSTEMATIC ACCOUNTS}

Phylum Porifera Grant, 1836

Class Demospongiae Sollas, 1885

Order Poecilosclerida Topsent, 1928

Suborder Microcionina Hajdu, van Soest and Hooper, 1994

*To whom correspondence should be addressed

Tel: 82-42-629-8755, Fax: 82-42-629-8751

E-mail: cjsim@hnu.kr
Family Microcionidae Cater, 1875

${ }^{1} *$ Clathria (Microciona) sinyangensis n. sp. (Figs. 1-2)

Material examined. Holotype (Por. 93), Sinyang (Seopjikoji) Intertidal Zone, Jejudo Island, 15 Oct. 2008, C.J. Sim, deposited in the National History Museum and Department of Biological Sciences, Hannam University, Daejeon, Korea. Description. Sponge thinly encrusting, less than $2 \mathrm{~mm}$ thick. Sponge tightly attached to rocky substrate. Size up to $3.5 \times$ $3 \mathrm{~cm}$ long, $2 \mathrm{~mm}$ thick. Oscules common visible. Surface superficially velvety, no dormal membrane. Texture firm. Skeleton structure dendritic structure ascending columns of principal subtylostyles. Choanosome consist of numerous ascending plumose tracts both cored and echinated by large subtylostyles from basal length of sponging measuring 100 $-240 \mu \mathrm{m}$ in diameter spongin fibers arise and project up-

Table 1. The comparison of characters between Clathria (Microciona) sinyangensis n. sp. and C. (M.) pennata

\begin{tabular}{cccc}
\hline \multicolumn{2}{c}{ Species } & $\begin{array}{c}\text { Clathria } \\
\text { Characters }\end{array}$ & $\begin{array}{c}\text { Clathria } \\
\text { (Microciona) } \\
\text { sinyangensis n. sp. } \\
\text { pennata }\end{array}$ \\
\hline Growth form & Thin encrusting & Encrusting \\
\hline Colour & Red & Orange \\
\hline \multirow{4}{*}{ Spicules } & Thick & $180-500 \times$ & $284-917 \times$ \\
& subtylostyle & $10-15$ & $17-36$ \\
& Thin & $165-430 \times$ & $225-452 \times$ \\
& subtylostyle & $2-5$ & $5-8$ \\
& Toxa I & $85-120$ & \\
& Toxa II & $45-70$ & $45-75$ \\
& Toxa III & $15-30$ & \\
\hline \multicolumn{4}{c}{} \\
\end{tabular}

$1 *$ 신양유령해면 (신칭) 

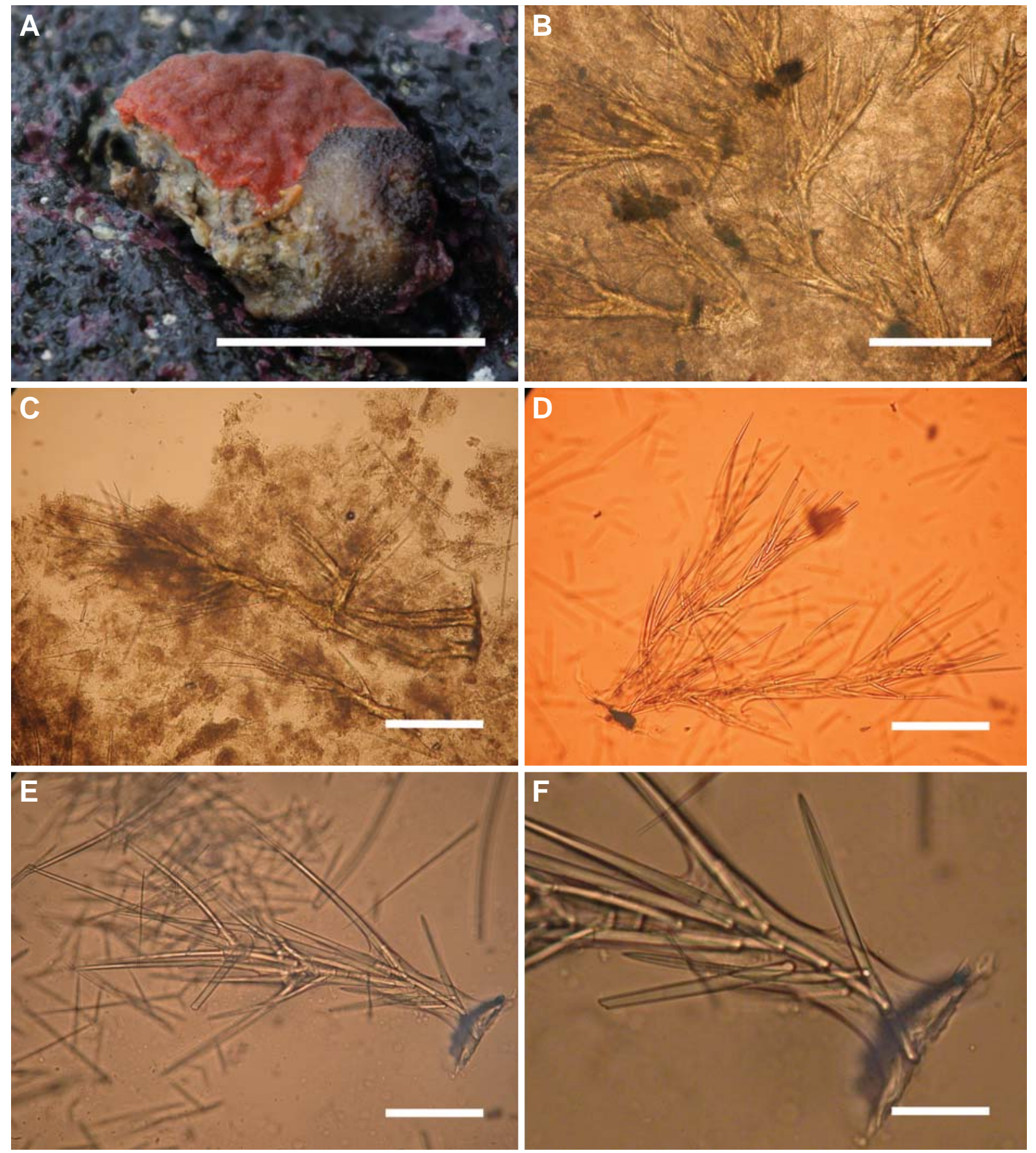

Fig. 1. Clathria (Microciona) sinyangensis $n$. $\mathrm{sp}$. A, entire animal; $B-E$, choanosomal skeleton; $F$, basal layer. $S c a l e ~ b a r s=3 \mathrm{~cm}(A), 1$ $\mathrm{mm}$ (B), $300 \mu \mathrm{m}$ (C-E), $150 \mu \mathrm{m}(\mathrm{F})$.

ward. Colour red in life which gradually changes to beige in alcohol. Spicules megascleres, two sizes of subtylostyle. Microscleres, three sizes of toxa.

Spicules

Megascleres

Thick

$180-500 \times 10-15 \mu \mathrm{m}$
Thin subtylostyle Microscleres

Toxa I

Toxa II

Toxa III

Etymology. This species is named
$165-430 \times 2-5 \mu \mathrm{m}$

$85-120 \mu \mathrm{m}$

$45-70 \mu \mathrm{m}$

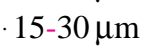



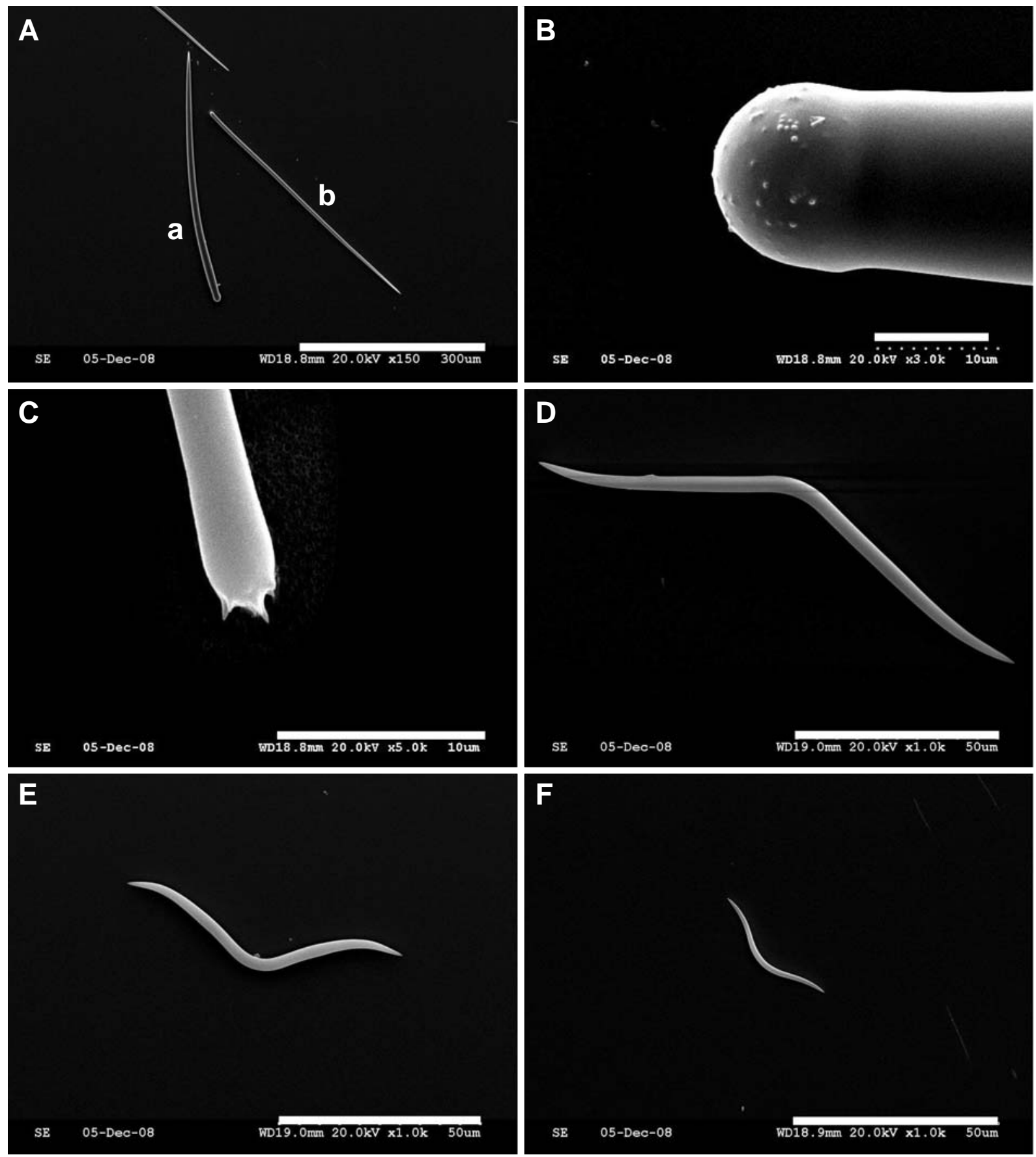

$\mathbf{F}$

Fig. 2. Clathria (Microciona) sinyangensis $n . s p . A$, Megascleres ( $a$, thick subtylostyle; $b$, thin subtylostyle); $B$, head of thick subtylostyle; C, head of thin subtylostyle; D, toxa I; E, toxa II; F, toxa III. Scale bars=300 $\mu \mathrm{m}(A, E), 50 \mu \mathrm{m}(D, F), 10 \mu \mathrm{m}(B, C)$.

koji, Sinyang, Jejudo Island, Korea.

Remarks. Clathria (Microciona) sinyangensis n. sp. is closely related to $C$. (M.) pennata Lambe, 1895 in their spicules, but the thick subtylostyle of $C$. (M.) sinyangensis n. sp. is smaller than that of $C$. $(M$.) pennata's. And the new species has toxa I and toxa III (Table 1), dermal membrane and oscules.

\section{ACKNOWLEDGEMENTS}

This research was supported by a grant from Marine Bio- 
technology Programme funded by Ministry of Land, Transport and Maritime Affairs of Korean Government.

\section{REFERENCES}

Hooper, J.N.A., 1996. Revision of the Microcionidae (Porifera: Poecilosclerida: Demosponiae) with description of Australian species. Mem. Queens Mus., 40: 1-626.

Hooper, J.N.A. and W.M. van Soest, 2002. Systema Porifera. A guide to the classification of sponges. Kluwer Academic/ Plenum Publishers Press, USA, pp. 1-1101.

Kim, H.J. and C.J. Sim., 2005. Two new marine sponges of genus Clathria (Clathria) (Poecilosclerida: Microcionidae) from Korea. Korean J. Syst. Zool., 21: 111-122.

Lambe, L.M., 1895. Sponges from the western coast North
America (1894). Proc. Trans. R. Soc. Can., 12(4): 138-713. Rho, B.J. and K.H. Lee, 1976. A survey of marine sponges of Haeundae and its adjacent water. J. Kor. Res. Inst. Better Liv., Ewha Womans Univ., 17: 93-111.

Rützler, K., 1978. Sponges in coral reefs. In Stoddart, D.R. and R.E. Johannes, eds., Coral Reefs: Research Methods. Monogr. Oceanogr. Neth. UNESCO, 5: 299-313.

Sim, C.J. and H.S. Byeon, 1989. A systematic study on the marine sponges in Korea. 9. Ceractinomorpha. Korean J. Syst. Zool., 5(1): 33-57.

Sim, C.J., Y.S. Kim and Y.H. Kim, 1992. A systematic study on the marine sponges in Korea. 10. Demosponges of Cheju Island. Korean J. Syst. Zool., 8(2): 301-324.

Received February 9, 2009 Accepted March 6, 2009 